\title{
IMPLEMENTATION OF GREEN MANUFACTURING IN INDUSTRY - A CASE STUDY
}

\author{
Swapnil V. Ghinmine ${ }^{1}$, Dilip I. Sangotra ${ }^{2}$ \\ ${ }^{1}$ Assistant Professor, Department of Mechanical Engineering DMIETR Wardha, Maharashtra India \\ ${ }^{2}$ Associates Professor, Department of Mechanical Engineering YCCE Nagpur, Maharashtra India
}

\begin{abstract}
The aim of this paper is to identify the factors that helps to implement the green manufacturing in the industry. The CO2 emission and the waste that is generated from the industry is one of the main factor for the environmental degradation which leads to global warming and acid rain. Government rules and regulation are the key important factors that helps achieve the environmental, economic and intangible performance. Data regarding the survey was collected and analyzed by the mean score. Implementation of these factors in the industry helps achieve economic growth at national and international level.
\end{abstract}

Keywords: Green design, training and employee involvement, green distribution, green manufacturing $* * *$

\section{INTRODUCTION}

Manufacturing plays an important role or strategic role in an organization especially to build competitive advantage and improve the performance of the manufacturing firm. With the rapid changes in the technologies, customers' needs and globalizations manufacturing is itself is transforming and evolving. In early $19^{\text {th }}$ century the production system adopted is mainly the mass production system without giving much stress on the green manufacturing. In 1970s the concept adopted is the flexible manufacturing system. As the progress is made in the manufacturing system the surrounding environment starts facing the problems of pollutions which leads to environmental degradations. The major challenge to the government was to protect the environment from these pollutions. So in $20^{\text {th }}$ century the concept of Green Manufacturing was evolved. The term "green" manufacturing can be looked in two ways: the manufacturing of "green" products, particularly those used in renewable energy systems and clean technology equipment of all kinds, and the "greening" of manufacturing - reducing pollution and waste by minimizing natural resource use, recycling and reusing what was considered waste, and reducing emissions.

\section{LITERATURE SURVEY}

Various case studies has been carried out by different authors on green manufacturing. Shang et al. (2010) [4] conducted a case study in which he has observed six different parameters of green supply chain management i.e eco design, green manufacturing and packaging, environmental participation, green marketing, stock and suppliers which helps to achieve the environmental performance. Lamming and Hampson (1996) [5] mainly focused on the concept of environmentally sound management and linked them to the supply chain management system establishing environmental procurement policy, collaborative supply strategies, vendor assessment and working with the suppliers to enable improvements. Handfield et al. (2002) [3] has made a multi attribute decision making model for measurement of the environmental performance. Walton et al. (1998) [9] has observed several many ways to increase the impact of procurement on green manufacturing. Quinghu Zhu et al (2008) [6] has identified different drivers such as Green Procurement, Internal Environmental Management, Eco Design, Customer Cooperation, and Investment Recovery which helps in the implementation of green supply chain management.

\subsection{Objective of the Study}

Objective of the study is to look after the factors or drivers and implementation of green manufacturing.

\subsection{Green Manufacturing}

Green manufacturing is a system that integrates product and process design issues with a issues of manufacturing, planning and control in such a manner to identify, quantify , assess and manage the flow of environmental waste with the goal of reducing and ultimately reducing environmental impact while also trying to maximize the resource efficiency.

\section{RESEARCH METHODOLOGY}

Research methodology consists of development of competitive strategies and benchmarking questionnaire about green. Manufacturing. These questionnaires were discussed with the industrial experts who believe to have the fair knowledge about the green practices that were followed in the industries. Performance of each of these strategies will depends upon the mean aggregate score. The ratings of these factors were marked on five point scale (1-good, 2average, 3-better, 4- excellent, 5- best) the extent to which they perceived their companies implementing each of the dimensions of green concept practices. These factors were 
analyzed on the basis of the mean score. These factors helps in the implementation of the green manufacturing and enabling organizations to evaluate their strength and weakness in the course of implementing these practices.

\section{IMPLEMENTATION OF GREEN} MANUFACTURING PROCESS

\begin{tabular}{|c|c|}
\hline Sr.No & IMPLEMENTATION PROCESS \\
\hline 1 & $\begin{array}{l}\text { Explaining how green considerations impact } \\
\text { on design decisions relating to } \\
\text { manufacturing processes and products }\end{array}$ \\
\hline 2 & 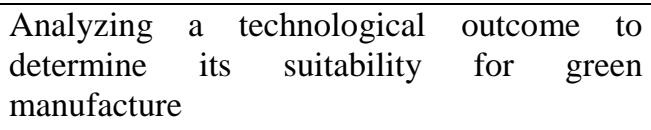 \\
\hline 3 & $\begin{array}{l}\text { Making design changes as required for the } \\
\text { technological outcome guided by good } \\
\text { design judgment criteria }\end{array}$ \\
\hline 4 & $\begin{array}{l}\text { Establishing specifications, including } \\
\text { tolerances, required of the outcome that is to } \\
\text { be manufactured within the constraints and } \\
\text { opportunities of the manufacturing location }\end{array}$ \\
\hline 5 & $\begin{array}{l}\text { Selecting a green manufacturing process and } \\
\text { quality control procedures to enable units to } \\
\text { meet the established specifications and } \\
\text { tolerances }\end{array}$ \\
\hline 6 & $\begin{array}{l}\text { Organizing resources and ensuring } \\
\text { procedures are carried out accurately in } \\
\text { keeping with relevant codes of practice }\end{array}$ \\
\hline 7 & $\begin{array}{l}\text { Monitoring the manufacturing process and } \\
\text { refining as required }\end{array}$ \\
\hline 8 & $\begin{array}{l}\text { Evaluating the success of the manufacturing } \\
\text { process in meeting green considerations }\end{array}$ \\
\hline 9 & $\begin{array}{l}\text { Justifying the level of success the } \\
\text { manufacturing process has attained in } \\
\text { meeting green considerations }\end{array}$ \\
\hline
\end{tabular}

\section{COMPRATIVE ANALYSIS OF FACTORS}

\subsection{Top Management Commitment (Mean Score}

\subsection{0)}

\begin{tabular}{|l|l|l|}
\hline Sr.No & $\begin{array}{l}\text { Top Management } \\
\text { Commitment }\end{array}$ & Mean Score \\
\hline 1 & $\begin{array}{l}\text { Focus on the } \\
\text { commitment and } \\
\text { responsibilities of } \\
\text { Green Manufacturing }\end{array}$ & 1.238 \\
\hline 2 & $\begin{array}{l}\text { Monitors the process } \\
\text { of GSCM }\end{array}$ & 1.174 \\
\hline 3 & $\begin{array}{l}\text { It mainly supports the } \\
\text { Green practices over } \\
\text { long budget }\end{array}$ & 1.539 \\
\hline
\end{tabular}

\begin{tabular}{|l|l|l|}
\hline 4 & $\begin{array}{l}\text { It makes changes in } \\
\text { current manufacturing } \\
\text { process to implement } \\
\text { Green Practices }\end{array}$ & 1.426 \\
\hline 5 & $\begin{array}{l}\text { It increases the profit } \\
\text { of the organization }\end{array}$ & 1.328 \\
\hline
\end{tabular}

\subsection{Green Purchasing (Mean Score 1.526)}

\begin{tabular}{|l|l|l|}
\hline Sr.No & Green purchasing & Mean Score \\
\hline 1 & $\begin{array}{l}\text { Purchasing of the } \\
\text { product and services } \\
\text { that has no adverse } \\
\text { effect on the } \\
\text { surrounding }\end{array}$ & 1.540 \\
\hline 2 & $\begin{array}{l}\text { It reduces overall } \\
\text { energy, cost and weight } \\
\text { of the product }\end{array}$ & 1.274 \\
\hline 3 & $\begin{array}{l}\text { It improves the } \\
\text { environmental } \\
\text { performance of the } \\
\text { organization }\end{array}$ & 1.384 \\
\hline 4 & $\begin{array}{l}\text { Collect information on } \\
\text { environmental product } \\
\text { and suppliers }\end{array}$ & 1.531 \\
\hline 5 & $\begin{array}{l}\text { It improves supplier } \\
\text { manufacturer } \\
\text { relationship }\end{array}$ & 1.529 \\
\hline
\end{tabular}

\subsection{Environmental Policy (Mean Score 1.726)}

\begin{tabular}{|c|c|c|}
\hline Sr.No & Environmental Policy & Mean Score \\
\hline 1 & $\begin{array}{l}\text { To protect and } \\
\text { conserve critical } \\
\text { ecological systems and } \\
\text { resources, and } \\
\text { invaluable natural and } \\
\text { man-made heritage, } \\
\text { which are essential for } \\
\text { life support, } \\
\text { livelihoods, economic } \\
\text { growth, a broad } \\
\text { and a a } \\
\text { conception of human } \\
\text { well-being }\end{array}$ & 1.326 \\
\hline 2 & $\begin{array}{l}\text { To ensure judicious } \\
\text { use of environmental } \\
\text { resources to meet the } \\
\text { needs and } \\
\text { aspirations of the } \\
\text { present and future } \\
\text { generations }\end{array}$ & 1.579 \\
\hline 3 & $\begin{array}{l}\text { To integrate } \\
\text { environmental } \\
\text { concerns into policies, } \\
\text { plans, programs, and } \\
\text { projects for economic } \\
\text { and social } \\
\text { development. }\end{array}$ & 1.259 \\
\hline 4 & To ensure efficient use & 1.423 \\
\hline
\end{tabular}




\begin{tabular}{|l|l|}
\hline of environmental \\
resources in the sense \\
of reduction \\
in their use per unit of \\
economic output, to \\
minimize adverse \\
environmental impacts
\end{tabular} \mid

\subsection{Green Design (Mean Score 1.448)}

\begin{tabular}{|l|l|l|}
\hline Sr.No & Green Design & Mean Score \\
\hline 1 & $\begin{array}{l}\text { Design of } \\
\text { product whose } \\
\text { composition and } \\
\text { design should } \\
\text { have minimum } \\
\text { negative impact } \\
\text { on the } \\
\text { environment }\end{array}$ & \\
\hline 2 & $\begin{array}{l}\text { It involves } \\
\text { recycling, reuse, } \\
\text { reduce, } \\
\text { remanufacturing, } \\
\text { disassembly }\end{array}$ & \\
\hline 3 & $\begin{array}{l}\text { It mainly focus } \\
\text { on the customer } \\
\text { requirement } \\
\text { while design the } \\
\text { product }\end{array}$ & \\
\hline
\end{tabular}

\subsection{Green Manufacturing (Mean Score 1.424)}

\begin{tabular}{|c|c|c|}
\hline Sr.No & $\begin{array}{l}\text { Green } \\
\text { Manufacturing }\end{array}$ & Mean Score \\
\hline 1 & $\begin{array}{l}\text { It involves } \\
\text { class of } \\
\text { technologies } \\
\text { that use } \\
\text { cleaner fuels } \\
\text { for generating } \\
\text { Power. } \\
\text { Examples } \\
\text { include } \\
\text { biomass, } \\
\text { hydro power, } \\
\text { Integrated Gas } \\
\text { Combined } \\
\text { Cycle (IGCC), } \\
\text { etc }\end{array}$ & 1.362 \\
\hline 2 & $\begin{array}{l}\text { use of Green } \\
\text { production } \\
\text { methods and } \\
\text { technologies in } \\
\text { traditional } \\
\text { Industries such } \\
\text { as iron and } \\
\text { steel, cement, } \\
\text { refining, } \\
\text { chemicals. }\end{array}$ & 1.578 \\
\hline 3 & $\begin{array}{l}\text { It helps in low } \\
\text { raw material }\end{array}$ & 1.423 \\
\hline
\end{tabular}

\begin{tabular}{|l|l|l|}
\hline & $\begin{array}{l}\text { cost, improve } \\
\text { production } \\
\text { efficiency, } \\
\text { reduce } \\
\text { environmental } \\
\text { impacts with } \\
\text { low or no } \\
\text { waste and } \\
\text { pollution }\end{array} \mid$ \\
\hline
\end{tabular}

\subsection{Green Distribution (Mean Score 1.440)}

\begin{tabular}{|l|l|l|}
\hline Sr.no & $\begin{array}{l}\text { Green } \\
\text { Distribution }\end{array}$ & Mean Score \\
\hline 1 & $\begin{array}{l}\text { It includes } \\
\text { transportation } \\
\text { of good with } \\
\text { minimum } \\
\text { environmental } \\
\text { impact. }\end{array}$ & \\
\hline 2 & $\begin{array}{l}\text { Transportation } \\
\text { system should } \\
\text { be fuel } \\
\text { efficient }\end{array}$ & \\
\hline 3 & $\begin{array}{l}\text { Environmental } \\
\text { friendly } \\
\text { vehicle like } \\
\text { solar vehicle } \\
\text { should be used }\end{array}$ & \\
\hline
\end{tabular}

5.7 Training and Employee Involvement (Mean Score 1.420)

\begin{tabular}{|l|l|l|}
\hline Sr.No & $\begin{array}{l}\text { Training and } \\
\text { employee } \\
\text { involvement }\end{array}$ & Mean Score \\
\hline 1 & $\begin{array}{l}\text { Workers from } \\
\text { different } \\
\text { departments } \\
\text { should come } \\
\text { together for } \\
\text { brainstorming } \\
\text { session }\end{array}$ & \\
\hline 2 & $\begin{array}{l}\text { Workers should } \\
\text { do the work at } \\
\text { there allocated } \\
\text { place }\end{array}$ & \\
\hline 3 & $\begin{array}{l}\text { Employee } \\
\text { should be } \\
\text { rewarded for } \\
\text { there innovative } \\
\text { ideas, in } \\
\text { involvement in } \\
\text { decision }\end{array}$ & \\
\hline 4 & $\begin{array}{l}\text { Involvement in } \\
\text { decision making } \\
\text { process } \\
\text { implementing } \\
\text { green concept }\end{array}$ & \\
\hline
\end{tabular}




\subsection{Customer Awareness Programme (Mean Score}

\subsection{0)}

\begin{tabular}{|l|l|l|}
\hline Sr.no & $\begin{array}{l}\text { Customer } \\
\text { Awareness } \\
\text { Programs }\end{array}$ & Mean Score \\
\hline 1 & $\begin{array}{l}\text { General } \\
\text { meetings be } \\
\text { should be } \\
\text { conducted for } \\
\text { GSCM }\end{array}$ & 1.429 \\
\hline 2 & $\begin{array}{l}\text { Feedback on } \\
\text { GSCM } \\
\text { products } \\
\text { should be done }\end{array}$ & 1.238 \\
\hline 3 & $\begin{array}{l}\text { Customer } \\
\text { requirements } \\
\text { survey should } \\
\text { be done. }\end{array}$ & 1.174 \\
\hline
\end{tabular}

\section{ANALYSIS OF FACTORS}

The present analysis shows that the most important factor is environmental policy which has the mean score of 1.726 followed by top management commitment (1.570), Green purchasing (1.526) , Green design (1.448) , Green distribution (1.440) , Green manufacturing (1.424) , Training and Employee involvement (1.420), Customer awareness program (1.340) .

\section{CONCLUSION}

The purpose of the study is to identify the Green manufacturing factors and its sub factors and its relationship with the organizational performance which include environmental performance, competitive advantage, and economic performance. The results shows that the industry with large manufacturing capacity can heavily invest on the green supply chain management than the industry with small manufacturing capacity. This is due to the larger firm has more investment capacity on green concept than the smaller firm. Thus it is concluded that to protect the environment and the earth appropriate methodology should be adopted by the industries to minimize the detrimental effect on the earth.

\section{REFERENCES}

[1]. L. K. Toke, R. C. Gupta, Milind Dandekar. 2010. Green Supply Chain Management; Critical Research and Practices. Proceedings of the 2010 International Conference on Industrial Engineering and Operations Management Dhaka, Bangladesh, January 9-10, 2010

[2]. Lynn Johannson, 1994. How Can ATQEM Approach Add Value to Your Supply Chain? In Journal Total Quality Environmental Management, pp. 521-530

[3]. Handfield, R., Walton, S., Sroufe, R., 2002.Applying environmental criteria to supplier assessment: A study of the application of theanalytical hierarchy process. European Journal of Operational Research 141, pp70-87.
[4.] K.C.Shang, C.S.Lu, S.Li 2010, A taxonomy of green supply chain management capability among electronic related manufacturing firms in Taiwan, Journal of environmental management, 91, pp1218-1226.

[5] Lamming, R.; Hampson, J., 1996. The environment as a supply chain management issue.Brit. J. Manage., 7 (Special issue 1), pp45-62.

[6]. Qinghua Zhu, Joseph Sarkis, Kee-hung Lai, 2008, Confirmation of a measurement model for green supply chain management practices implementation, Int. J. Production Economics ,111, pp261-273

[7]. Ramudhin A., Chaabane, A.2010, Carbon market sensitive sustainable supply chain network design, International Journal of Management Science and Engineering Management, 5 (1), pp30-38.

[8]. Seok Jin Lim, Suk Jae Jeong, Kyung Sup Kim , MyonWoong Park, 2006, Hybrid approach to distribution planning reflecting a stochastic supply chain, Int $J A d v$ Manuf Technol, 28: pp618-625.

[9]. Walton, S.V., Handfield, R.B., Melnyk, S.T., 1998, The green supply chain: Integrating suppliers into environmental management process, International Journal of Purchasing and Materials Management, Spring,pp 2-11.

[10] Zhu, Q.; Sarkis, J., 2006. An inter-sectoral comparison of green supply chain management in China: Drivers and practices, J. Clean. Prod., 14, pp472-486.

[11]. Holt, Diane and Ghobadian, Abby, (2009). An empirical study of green supply chain management practices amongst UK manufacturers, Journal of Manufacturing Technology Management, 20(7), 933-956.

[12]. Hsu, Chia-W. and Hu, Allen H., (2008), Green supply chain management in the electronic industry, International Journal of Environmental Science Technology, 5(2),205216.

[13]. Kumar, S., Chattopadhyaya, S. and Sharma, V., (2012), Green supply chain management: A case study from Indian electrical and electronics industry, International Journal of Soft Computing and Engineering , 1(6), 275-281. [14]. Lippmann, S., 1999, Supply chain environmental management elements for success, Environmental Management, 6(2), 175-182.

[15]. Malczewski, J., (1999), GIS and Multicriteria Desision Analysis, John Willey and Sons, Inc., New York.

[16]. Mudgal, R. K., Shankar, R., Talib, P. and Tilak, R., (2009), Greening the supply chain practices: an Indian perspective of enablers relationships, International Journal of Advanced Operations Management, 1(2/3),51-176.

[17]. Mudgal, R. K., Shankar, R., Talib, P. and Tilak, R., 2010, Modelling the barriers of green supply chain practices: an Indian perspective, International Journal of Logistics Systems and Management, 7(1),81- 107. 